\title{
PERBEDAAN KESIAPAN GURU IPS SMP KABUPATEN SLEMAN \\ DALAM IMPLEMENTASI PEMBELAJARAN IPS BERBASIS \\ KURIKULUM 2013
}

\author{
Saliman \\ Anik Widiastuti \\ Supardi \\ Jurusan Pendidikan IPS Fakultas Ilmu Sosial UNY \\ Email: anikwidiastuti@uny.ac.id, No.Hp 085213323505
}

\begin{abstract}
Abstrak
Pemberlakuan kurikulum 2013 berdampak pada implementasi pembelajaran IPS di SMP. Penelitian ini bertujuan untuk: 1) mengetahui perbedaan kesiapan guru IPS SMP Kabupaten Sleman dalam implementasi pembelajaran IPS berbasis kurikulum 2013 ditinjau berdasar jenis kelamin; 2) mengetahui perbedaan kesiapan guru IPS SMP Kabupaten Sleman dalam implementasi pembelajaran IPS berbasis kurikulum 2013 ditinjau berdasar tingkat pendidikan; 3) mengetahui perbedaan kesiapan guru IPS SMP Kabupaten Sleman dalam implementasi pembelajaran IPS berbasis kurikulum 2013 ditinjau berdasar pengalaman mengajar; 4) mengetahui perbedaan kesiapan guru IPS SMP Kabupaten Sleman dalam implementasi pembelajaran IPS berbasis kurikulum 2013 ditinjau berdasar keikutsertaan diklat. Penelitian ini merupakan penelitian desktiptif eksploratif dengan pendekatan kuantitatif. Populasi penelitian yaitu guru IPS SMP Kabupaten Sleman yaitu sebanyak 239 guru. Sampel penelitian diambil sebanyak 25\% yaitu 60 guru. Teknik pengumpulan data menggunakan angket. Hasil penelitian menunjukkan bahwa: 1) tidak terdapat perbedaan kesiapan guru IPS SMP Kabupaten Sleman dalam implementasi pembelajaran IPS berbasis kurikulum 2013 ditinjau berdasar jenis kelamin; 2) tidak terdapat perbedaan kesiapan guru IPS SMP Kabupaten Sleman dalam implementasi pembelajaran IPS berbasis kurikulum 2013 ditinjau berdasar tingkat pendidikan; 3) terdapat perbedaan kesiapan guru IPS SMP Kabupaten Sleman dalam implementasi pembelajaran IPS berbasis kurikulum 2013 ditinjau berdasar pengalaman mengajar; 4) terdapat perbedaan kesiapan guru IPS SMP Kabupaten Sleman dalam implementasi pembelajaran IPS berbasis kurikulum 2013 ditinjau berdasar keikutsertaan diklat.
\end{abstract}

Kata kunci: kesiapan, kurikulum 2013, pembelajaran IPS 


\begin{abstract}
Curriculum enactment in 2013 made an impact on the implementation of social studies learning in junior high school. This study aims to: 1) investigate the difference readiness social studies teacher at junior high school in Sleman regency in the implementation of social studies learning in curriculum 2013-based are reviewed based on sex; 2) investigate the difference readiness social studies teacher at junior high school in Sleman regency in the implementation of social studies learning in curriculum 2013-based are reviewed based on the level of education; 3) investigate the difference readiness social studies teacher at junior high school in Sleman regency in the implementation of social studies learning in curriculum 2013-based are reviewed based on the experience of teaching; 4) investigate the difference readiness social studies teacher junior at high school in Sleman regency in the implementation of social studies learning in curriculum 2013-based are reviewed based on training participation. This research is a descriptive exploratory study with a quantitative approach. The study population is a social studies teacher at junior high school in Sleman regency included in the scope of the Department of Education Youth and Sports Sleman as many as 239 teachers. Samples were taken at 25\% of the population by random sampling technique as many as 60 teachers. The technique of collecting data using questionnaires. The results showed that: 1) there is no readiness difference in social studies teacher at junior high school in Sleman regency in the implementation of social studies learning in curriculum 2013-based are reviewed based on sex; 2) there is no readiness difference in social studies teacher at junior high school in Sleman regency in the implementation social studies learning in curriculum 2013-based are reviewed based on the level of education; 3) there is a readiness difference in social studies teacher at junior high school in Sleman regency in the implementation of social studies learning in curriculum 2013-based are reviewed based on the experience of teaching; 4) there is a readiness difference in social studies teacher at junior high school in Sleman regency in the implementation of social studies learning in curriculum 2013-based are reviewed based on training participation.
\end{abstract}

\title{
Keywords: readiness, curriculum 2013, learning IPS
}




\section{Pendahuluan}

Salah satu unsur penting dalam penyelenggaraan pendidikan adalah kurikulum. Kurikulum merupakan seperangkat rancangan program pendidikan dari penyelenggara pendidikan yang akan diberikan kepada peserta didiknya. Kurikulum secara etimologis adalah tempat berlari yang berasal dari bahasa latin curir yang artinya pelari dan curere yang artinya tempat berlari (Imas Kurniasih \& Berlin Sani, 2014: 3). Pengertian kurikulum juga tercantum dalam Undang-Undang No. 20 Tahun 2003 tentang Sistem Pendidikan Nasional pasal 1 butir 19, disebutkan bahwa kurikulum adalah seperangkat rencana dan pengaturan mengenai tujuan, isi, dan bahan pelajaran serta cara yang digunakan sebagai pedoman penyelenggaraan kegiatan pembelajaran untuk mencapai tujuan pendidikan tertentu. Kurikulum harus mampu mengikuti tuntutan perkembangan jaman dan kebutuhan dunia kerja. Oleh karena itu demi mewujudkan pendidikan yang baik, kurikulum harus senantiasa diubah disesuaikan dengan perkembangan jaman.

Pada tahun 2013 di Indonesia terjadi pergantian kurikulum pendidikan dari KTSP (Kurikulum Tingkat Satuan Pendidikan) menjadi kurikulum 2013. Dalam Permendikbud No. 68 tahun 2013, kurikulum 2013 dikembangkan atas teori pendidikan berdasarkan standar dan teori kurikulum berbasis kompetensi (Kemdikbud, 2013). Terdapat tiga kompetensi yang ditekankan dalam kurikulum 2013 yaitu kompetensi sikap, kompetensi pengetahuan, dan kompetensi keterampilan peserta didik. Kompetensi tersebut diharapkan dapat dimiliki siswa sehingga membentuk siswa sebagai manusia seutuhnya yang tidak hanya cerdas tetapi memiliki karakter yang baik dan memiliki 
keterampilan. Hal ini diharapkan dapat dikembangkan lebih optimal melalui kurikulum 2013.

Pergantian kurikulum merupakan salah satu bentuk kebijakan pemerintah sebagai upaya memperbaiki bidang pendidikan. Pergantian kurikulum menjadi kurikulum 2013 tentunya berpengaruh pada berbagai hal, yang salah satunya adalah kesiapan guru sebagai pelaksana untuk mengimplementasikannya dalam proses pembelajaran. Guru mau tidak mau dituntut untuk mempelajari dan memahami isi dan tujuan kurikulum 2013 agar dalam implementasinya berhasil baik.

Kebijakan penggantian kurikulum oleh pemerintah mengharuskan guru untuk mampu mengimplementasikan pembelajaran berbasis kurikulum 2013, begitu halnya dalam pembelajaran IPS di SMP. Istilah Ilmu Pengetahuan Sosial (IPS) merupakan nama mata pelajaran di tingkat sekolah dasar dan menengah atau nama program studi di perguruan tinggi yang identik dengan istilah "social studies" dalam kurikulum persekolahan di negara lain, khususnya di Australia dan Amerika (Sapriya, 2012: 19). Pembelajaran IPS di SMP mengalami perubahan dari yang sebelumnya dikaji berdasar bidang studi ekonomi, sejarah, geografi, dan sosiologi menjadi pembelajaran tematik dengan pendekatan terpadu. Pembelajaran IPS dalam bentuk tematik dengan pendekatan terpadu merupakan sesuatu yang baru bagi guru IPS SMP di Kabupaten Sleman. sehingga diperlukan kesiapan guru dalam implementasi pembelajaran IPS berbasis kurikulum 2013.

Guru IPS SMP Kabupaten Sleman memiliki heterogenitas latar belakang yang tentunya hal ini mempengaruhi perbedaan kesiapan antar guru yang satu dengan guru yang lainnya. 
Menurut James Dreves "Kesiapan adalah seluruh kondisi seseorang yang membuatnya siap untuk memberi respon atau jawaban didalam cara tertentu terhadap suatu situasi" (Slameto, 2010: 113). Pendapat lain dikemukaan oleh Suharsimi Arikunto (2006: 54) bahwa "kesiapan adalah suatu kompetensi sehingga seseorang yang memiliki kompetensi berarti seseorang tersebut memiliki kesiapan yang cukup untuk berbuat sesuatu".

Kesiapan sangat perlu diperhatikan dalam suatu proses, karena jika seseorang sudah memiliki kesiapan, maka hasilnya akan memuaskan. Kesiapan yang dimaksud dalam penelitian ini adalah kesiapan guru dalam implementasi pembelajaran IPS berbasis kurikulum 2013 yaitu kondisi yang membuat guru memiliki kompetensi untuk siap melakukan atau mempraktikkan pembelajaran IPS berbasis kurikulum 2013.

Ciri-ciri seseorang yang telah mempunyai kesiapan kerja menurut Hermanto Sofyan (1991) bahwa untuk mencapai tingkat kesiapan kerja dipengaruhi oleh tiga hal meliputi:

\section{1) Tingkat Kematangan}

Tingkat kematangan menunjukkan pada proses perkembangan atau pertumbuhan yang sempurna, dalam arti siap digunakan.

2) Pengalaman Sebelumnya

Pengalaman sebelumnya merupakan pengalaman-pengalaman yang diperoleh berkaitan dengan lingkungan, kesempatankesempatan yang tersedia dan pengaruh dari luar yang tidak disengaja.

3) Keadaan Mental dan Emosi yang Serasi

Keadaan mental dan emosi yang serasi meliputi keadaan kritis, memiliki pertimbangan yang logis, obyektif, bersikap dewasa, kemauan untuk bekerja dengan orang lain, mempunyai 
kesempatan untuk menerima, kemauan untuk maju serta mengembangkan keahlian yang dimiliki.

Berdasarkan ciri-ciri yang dikemukakan oleh Hermanto Sofyan di atas, dapat diketahui bahwa untuk membedakan kesiapan guru IPS SMP Kabupaten Sleman dalam implementasi pembelajaran IPS berbasis kurikulum 2013 dapat mengacu pada tingkat kematangan, pengalaman sebelumnya, serta keadaan mental dan emosi yang serasi.

Tentunya kesiapan tidak hanya dipengaruhi oleh satu faktor saja, tetapi dipengaruhi oleh banyak faktor. Menurut Kartini Kartono (1991: 21), faktor-faktor yang mempengaruhi kesiapan adalah faktor-faktor dari dalam diri sendiri/intern (meliputi kecerdasan, ketrampilan dan kecakapan, bakat, kemampuan dan minat, motivasi, kesehatan, kebutuhan psikologis, kepribadian, cita-cita, dan tujuan dalam bekerja) dan faktor-faktor dari luar diri sendiri/ekstern (meliputi lingkungan keluarga (rumah), lingkungan dunia kerja, rasa aman dalam pekerjaannya, kesempatan mendapatkan kemajuan, rekan sekerja, hubungan dengan pimpinan, dan gaji). Pendapat lain dikemukakan oleh George J. Moully (Rika Isharyanti, 2011: 17) "kesiapan tidak tergantung pada kematangan semata-mata tetapi termasuk juga di dalamnya faktor-faktor lain misalnya motivasi dan pengalaman, keadaan ekonomi orang tua, bimbingan sosial. Sedangkan menurut Slameto (2010: 113), faktor-faktor yang mempengaruhi kesiapan mencakup tiga aspek, yaitu: (1) Kondisi fisik, mental dan emosional, (2) Kebutuhan-kebutuhan, motif dan tujuan, (3) Keterampilan, pengetahuan dan pengertian lain yang telah dipelajari. Pendapat lain dari Dalyono (2005: 166), menyebutkan bahwa kesiapan berkaitan dengan beberapa faktor, yaitu: 
1) Perlengkapan dan pertumbuhan fisiologis, ini menyangkut pertumbuhan terhadap kelengkapan pribadi seperti tubuh pada umumnya, alat-alat indera dan kapasitas intelektual.

2) Motivasi, yang menyangkut kebutuhan, minat serta tujuantujuan individu untuk mempertahankan serta mengembangkan diri.

Kesiapan guru dalam implementasi pembelajaran IPS berbasis kurikulum 2013 akan menentukan keberhasilan pencapaian tujuan pembelajaran yang dilakukan oleh guru. Karena banyaknya faktor yang mempengaruhi kesiapan dan melihat permasalahan di atas maka penelitian ini ingin mengetahui perbedaan kesiapan guru IPS SMP di Kabupaten Sleman dalam implementasi pembelajaran IPS berbasis kurikulum 2013. Secara terperinci, penelitian ini bertujuan untuk mengetahui:

1. Perbedaan kesiapan guru IPS SMP di Kabupaten Sleman dalam implementasi pembelajaran IPS berbasis kurikulum 2013 ditinjau berdasar jenis kelamin.

2. Perbedaan kesiapan guru IPS SMP di Kabupaten Sleman dalam implementasi pembelajaran IPS berbasis kurikulum 2013 ditinjau berdasar tingkat pendidikan.

3. Perbedaan kesiapan guru IPS SMP di Kabupaten Sleman dalam implementasi pembelajaran IPS berbasis kurikulum 2013 ditinjau berdasar lama mengajar.

4. Perbedaan kesiapan guru IPS SMP di Kabupaten Sleman dalam implementasi pembelajaran IPS berbasis kurikulum 2013 ditinjau berdasar keikutsertaan diklat.

\section{Metode Penelitian}

Penelitian ini merupakan penelitian deskriptif eksploratif, karena hanya bertujuan menggambarkan keadaan atau fenomena yang terjadi di lapangan yaitu melukiskan atau menggambarkan 
kesiapan guru IPS SMP Kabupaten Sleman dalam implementasi pembelajaran IPS berbasis kurikulum 2013. Pendekatan yang digunakan dalam penelitian ini adalah pendekatan kuantitatif karena data yang terkumpul berwujud angka-angka dan diolah dengan menggunakan analisis statistik dengan bantuan program SPSS 17 for windows.

Penelitian ini dilakukan di SMP yang terletak di Kabupaten Sleman dengan subjek penelitian guru IPS SMP dalam lingkup Dinas Pendidikan. Penelitian dilakukan mulai bulan April sampai dengan Oktober 2014 dengan waktu pengambilan data lapangan pada bulan Juli sampai dengan bulan September 2014.

Populasi penelitian adalah seluruh guru IPS SMP Kabupaten Sleman yang termasuk dalam lingkup Dinas Pendidikan Kabupaten Sleman. Berdasarkan data dari Dinas Pendidikan Kabupaten Sleman, guru IPS SMP berjumlah 239 orang. Penelitian ini mengambil sampel sebanyak $25 \%$ dari total populasi yaitu sebanyak 59,75 atau dibulatkan menjadi 60 guru yang diambil dengan teknik random sampling. Pengumpulan data penelitian dilakukan dengan angket yang berisi seperangkat pertanyaan atau pernyataan yang diisi secara langsung oleh guru IPS SMP Kabupaten Sleman yang menjadi responden.

Analisis yang digunakan adalah analisis statistik yang meliputi mean, median, modus, dan standar deviasi. Sesuai dengan tujuan penelitian teknik analisis data yang digunakan dalam penelitian ini adalah teknik analisis statistik deskriptif dengan persentase untuk menggambarkan keadaan dari subjek.Langkah-langkah dalam analisis tersebut adalah melalui editing, koding, tabulasi data, dan analisis data.

Hipotesis dalam penelitian ini dapat dirumuskan sebagai berikut: 
JIPSINDO No. 2, Volume 3, September 2016

1. Terdapat perbedaan kesiapan guru IPS SMP Kabupaten Sleman dalam implementasi pembelajaran IPS berbasis kurikulum 2013 ditinjau berdasar jenis kelamin

Ho1 ditolak, dan Ha1 diterima jika signifikansi < dari 0,05

Ho1 diterima, dan Ha1 ditolak jika signifikansi > dari 0,05

2. Terdapat perbedaan kesiapan guru IPS SMP Kabupaten Sleman dalam implementasi pembelajaran IPS berbasis kurikulum 2013 ditinjau berdasar tingkat pendidikan

Ho2 ditolak, dan Ha2 diterima jika signifikansi < dari 0,05

Ho2 diterima, dan Ha2 ditolak jika signifikansi > dari 0,05

3. Terdapat perbedaan kesiapan guru IPS SMP Kabupaten Sleman dalam implementasi pembelajaran IPS berbasis kurikulum 2013 ditinjau berdasar lama mengajar

Ho3 ditolak, dan Ha3 diterima jika signifikansi < dari 0,05

Ho3 diterima, dan Ha3 ditolak jika signifikansi > dari 0,05

4. Terdapat perbedaan kesiapan guru IPS SMP Kabupaten Sleman dalam implementasi pembelajaran IPS berbasis kurikulum 2013 ditinjau berdasar keikutsertaan diklat kurikulum 2013

Ho4 ditolak, dan Ha4 diterima jika signifikansi < dari 0,05

Ho4 diterima, dan Ha4 ditolak jika signifikansi > dari 0,05

\section{Hasil Penelitian}

1. Kesiapan guru IPS SMP Kabupaten Sleman dalam implementasi pembelajaran IPS berbasis kurikulum 2013 ditinjau berdasar jenis kelamin

Data tentang kesiapan guru IPS SMP Kabupaten Sleman dalam implementasi pembelajaran IPS berbasis kurikulum 2013 ditinjau berdasar jenis kelamin dilakukan dengan analisis crosstabs atau tabulasi silang di bawah ini. 
Tabel 1 Crosstabs Kesiapan guru IPS SMP Kabupaten Sleman dalam implementasi pembelajaran IPS berbasia kurikulum 2013 berdasar jenis kelamin

Jenis Kelamin * Kesiapan guru IPS... Crosstabulation

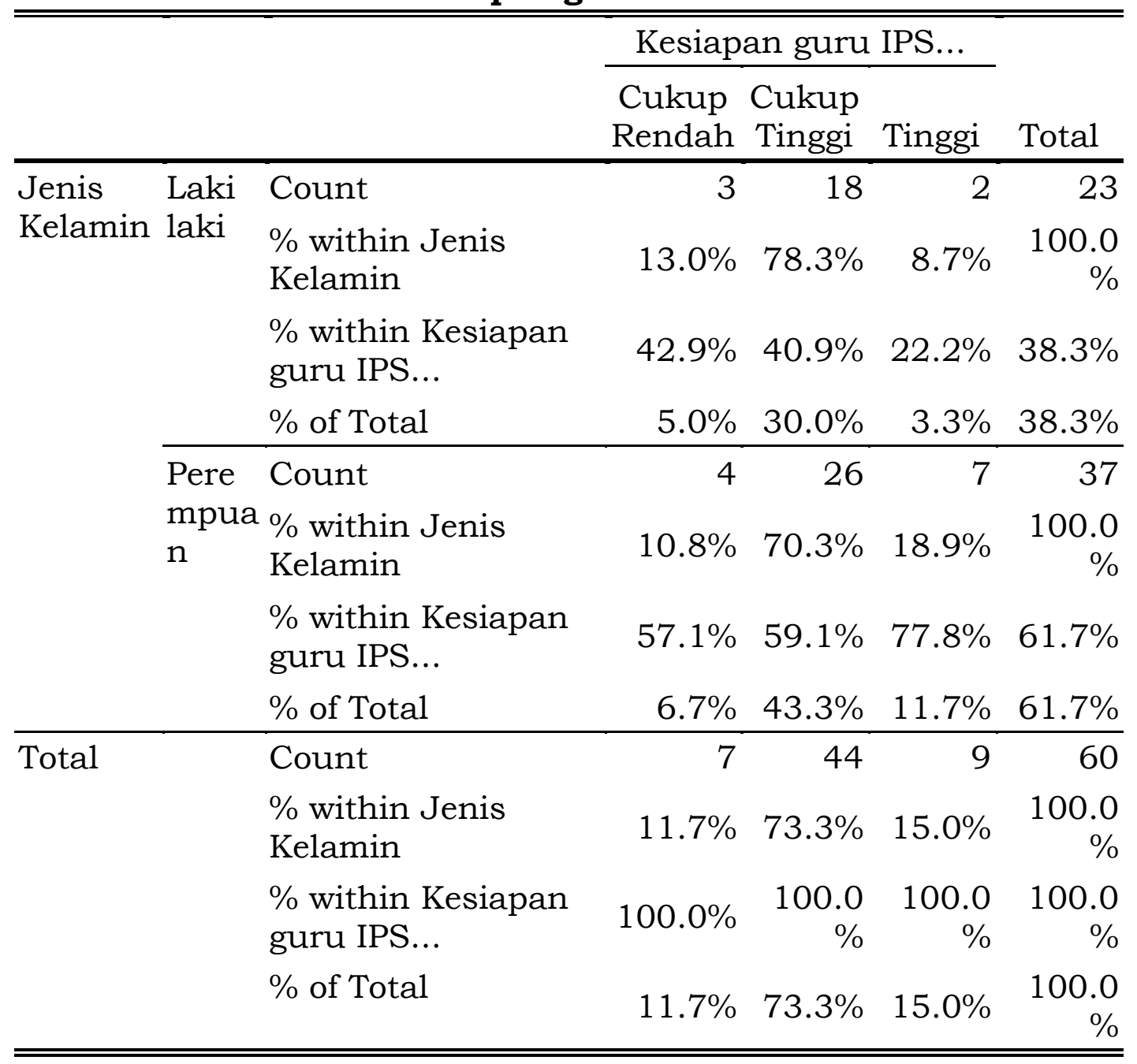

(Sumber: data primer yang diolah, 2014)

Untuk mengetahui ada tidaknya perbedaan kesiapan dalam implementasi pembelajaran IPS berbasis kurikulum 2013 antara guru berjenis kelamin laki-laki dan perempuan berdasar analisis statistik, dilakukan uji beda dengan Chi Square yang hasilnya dapat dilihat dalam tabel 2 . 
Tabel 2. Chi-Square Tests

\begin{tabular}{lrrr}
\hline \hline & Value & df & $\begin{array}{c}\text { Asymp. Sig. } \\
(2 \text {-sided })\end{array}$ \\
\hline Pearson Chi-Square & $1.172^{\mathrm{a}}$ & 2 & .556 \\
Likelihood Ratio & 1.251 & 2 & .535 \\
Linear-by-Linear & .815 & 1 & .367 \\
Association & 60 & & \\
N of Valid Cases & & & \\
\hline \hline
\end{tabular}

a. 3 cells $(50.0 \%)$ have expected count less than 5 . The minimum expected count is 2.68 .

Dari hasil analisis Chi Square di atas, perhitungan uji beda signifikansi diperoleh nilai signifikansi sebesar 0,556. Hasil tersebut menunjukkan bahwa nilai signifikansi yang diperoleh lebih besar dari nilai signifikansi yang telah ditetapkan sebesar 0,05 maka Ho diterima dan Ha ditolak sehingga dapat disimpulkan tidak ada perbedaan kesiapan guru laki-laki dan perempuan dalam implementasi pembelajaran IPS berbasis kurikulum 2013. Tabel 1 menunjukkan bahwa kesiapan guru laki-laki didominasi oleh guru yang termasuk dalam kategori cukup tinggi, begitu pula kesiapan guru perempuan didominasi oleh guru yang termasuk dalam kategori cukup tinggi, sehingga dapat dikatakan tidak ada perbedaan kesiapan. Hal ini diperkuat dengan hasil analisis Chi Square yang menunjukkan tidak adanya perbedaan kesiapan antara guru laki-laki dan guru perempuan.

Jenis kelamin menurut teori merupakan faktor fisik yang mempengaruhi kesiapan seseorang, akan tetapi hasil penelitian yang diperoleh mengenai kesiapan dalam implementasi pembelajaran IPS berbasis kurikulum 2013 tidak dipengaruhi jenis kelamin. Hal ini dimungkinkan karena kesempatan guru untuk memperoleh pengetahuan terhadap suatu kebijakan antara laki-laki dan perempuan adalah sama. 
2. Kesiapan guru IPS SMP Kabupaten Sleman dalam implementasi pembelajaran IPS berbasis kurikulum 2013 ditinjau berdasar tingkat pendidikan

Data tentang kesiapan guru IPS SMP Kabupaten Sleman terhadap IPS dalam implementasi pembelajaran IPS berbasis kurikulum 2013 ditinjau berdasar jenis kelamin dilakukan dengan analisis crosstabs atau tabulasi silang yang dapat dilihat pada tabel di bawah ini.

Tabel 3 Kesiapan guru dalam implementasi pembelajaran

IPS berbasis kurikulum 2013 berdasar tingkat pendidikan

Tingkat Pendidikan * Kesiapan guru IPS... Crosstabulation

\begin{tabular}{|c|c|c|c|c|c|c|}
\hline & & & Kesiap & an guru & IPS.. & \\
\hline & & & $\begin{array}{l}\text { Cukup } \\
\text { Rendah }\end{array}$ & $\begin{array}{l}\text { Cukup } \\
\text { Tinggi }\end{array}$ & Tinggi & Total \\
\hline Tingkat & PGSL & Count & 0 & 1 & 0 & 1 \\
\hline $\begin{array}{l}\text { Pendidi } \\
\text { kan }\end{array}$ & & $\begin{array}{l}\text { \% within Tingkat } \\
\text { Pendidikan }\end{array}$ & $.0 \%$ & $\begin{array}{r}100.0 \\
\%\end{array}$ & $.0 \%$ & $\begin{array}{r}100.0 \\
\%\end{array}$ \\
\hline & & $\begin{array}{l}\text { \% within Kesiapan } \\
\text { guru IPS... }\end{array}$ & $.0 \%$ & $2.3 \%$ & $.0 \%$ & $1.7 \%$ \\
\hline & & $\%$ of Total & $.0 \%$ & $1.7 \%$ & $.0 \%$ & $1.7 \%$ \\
\hline & Diplo & Count & 0 & 2 & 0 & 2 \\
\hline & & $\begin{array}{l}\text { \% within Tingkat } \\
\text { Pendidikan }\end{array}$ & $.0 \%$ & $\begin{array}{r}100.0 \\
\%\end{array}$ & $.0 \%$ & $\begin{array}{r}100.0 \\
\%\end{array}$ \\
\hline & & $\begin{array}{l}\text { \% within Kesiapan } \\
\text { guru IPS... }\end{array}$ & $.0 \%$ & $4.5 \%$ & $.0 \%$ & $3.3 \%$ \\
\hline & & $\%$ of Total & $.0 \%$ & $3.3 \%$ & $.0 \%$ & $3.3 \%$ \\
\hline & Sarjan & Count & 7 & 40 & 7 & 54 \\
\hline & $\mathrm{a}$ & $\begin{array}{l}\text { \% within Tingkat } \\
\text { Pendidikan }\end{array}$ & $13.0 \%$ & $74.1 \%$ & $13.0 \%$ & $\begin{array}{r}100.0 \\
\%\end{array}$ \\
\hline & & $\begin{array}{l}\% \text { within Kesiapan } \\
\text { guru IPS... }\end{array}$ & $100.0 \%$ & $90.9 \%$ & $77.8 \%$ & $90.0 \%$ \\
\hline & & $\%$ of Total & $11.7 \%$ & $66.7 \%$ & $11.7 \%$ & $90.0 \%$ \\
\hline & Magist & Count & 0 & 1 & 2 & 3 \\
\hline
\end{tabular}




\begin{tabular}{llrrrr}
\hline \multirow{2}{*}{ er } & $\begin{array}{l}\text { \% within Tingkat } \\
\text { Pendidikan }\end{array}$ & $.0 \%$ & $33.3 \%$ & $66.7 \%$ & $\begin{array}{r}100.0 \\
\%\end{array}$ \\
& \% within Kesiapan & & & & \\
& guru IPS... & $.0 \%$ & $2.3 \%$ & $22.2 \%$ & $5.0 \%$ \\
& \% of Total & $.0 \%$ & $1.7 \%$ & $3.3 \%$ & $5.0 \%$ \\
\hline Total & Count & 7 & 44 & 9 & 60 \\
& \% within Tingkat & $11.7 \%$ & $73.3 \%$ & $15.0 \%$ & 100.0 \\
& Pendidikan & & 100.0 & 100.0 & 100.0 \\
& \% within Kesiapan & $100.0 \%$ & $\%$ & $\%$ & $\%$ \\
& guru IPS... & & & & $\%$ \\
& $\%$ of Total & $11.7 \%$ & $73.3 \%$ & $15.0 \%$ & 100.0 \\
& & & & & $\%$ \\
\hline \hline
\end{tabular}

(Sumber: data primer yang diolah, 2014)

Untuk mengetahui ada tidaknya perbedaan kesiapan dalam pembelajaran IPS berbasis kurikulum 2013 antara guru berpendidikan terakhir PGSLP, diploma 3, sarjana, dan magister berdasar analisis statistik, dilakukan uji beda dengan Chi Square yang hasilnya dapat dilihat dalam tabel 4.

Tabel 4

\section{Chi-Square Tests}

\begin{tabular}{lrrr}
\hline \hline & Value & df & $\begin{array}{c}\text { Asymp. Sig. } \\
(2 \text {-sided })\end{array}$ \\
\hline Pearson Chi-Square & $7.666^{\mathrm{a}}$ & 6 & .264 \\
Likelihood Ratio & 6.486 & 6 & .371 \\
Linear-by-Linear & 1.704 & 1 & .192 \\
Association & 60 & & \\
N of Valid Cases & & & \\
\hline \hline
\end{tabular}

a. 9 cells $(75.0 \%)$ have expected count less than 5 . The minimum expected count is .12 .

Dari hasil analisis Chi Square di atas, perhitungan uji beda signifikansi diperoleh nilai signifikansi sebesar 0,264. Hasil tersebut menunjukkan bahwa nilai signifikansi yang diperoleh lebih besar dari nilai signifikansi yang telah ditetapkan sebesar 0,05 maka Ho diterima dan Ha ditolak sehingga dapat disimpulkan 
tidak ada perbedaan kesiapan guru berpendidikan terakhir PGSLP, diploma, sarjana, dan magister dalam implementasi pembelajaran IPS berbasis kurikulum 2013. Perbedaan yang terlihat pada tabel 3 tidak terlalu signifikan sehingga tidak dianggap berarti, atau dapat dikatakan bahwa tidak terdapat perbedaan kesiapan guru dalam implementasi pembelajaran IPS berbasis kurikulum 2013 ditinjau berdasar tingkat pendidikan.

Hal ini dimungkinkan karena perbedaan tingkat pendidikan tidak serta merta menyebabkan perbedaan pengetahuan dan wawasan mengenai suatu kebijakan termasuk dalam hal ini mengenai implementasi pembelajaran IPS berbasis kurikulum 2013. Belum tentu guru yang pendidikannya tinggi lebih siap untuk mengimplementasikan kebijakan yang diterapkan pemerintah.

3. Kesiapan guru IPS SMP Kabupaten Sleman dalam implementasi pembelajaran IPS berbasis kurikulum 2013 ditinjau berdasar lama mengajar

Data tentang kesiapan guru IPS SMP Kabupaten Sleman terhadap IPS dalam implementasi pembelajaran IPS berbasis kurikulum 2013 ditinjau berdasar lama mengajar dilakukan dengan analisis crosstabs atau tabulasi silang di bawah ini.

Tabel 5. Kesiapan guru dalam implementasi pembelajaran IPS berbasis kurikulum 2013 berdasar lama mengajar

Lama Mengajar (thn) * Kesiapan guru IPS... Crosstabulation

\begin{tabular}{llrrrr}
\hline \hline & & \multicolumn{3}{c}{ Kesiapan guru IPS... } & \\
\cline { 3 - 5 } & & $\begin{array}{c}\text { Cukup } \\
\text { Rendah }\end{array}$ & Tingup & & \\
& & 0 & 6 & 0 & 6 \\
\hline Lama Mengajar & $<10$ th & Count & & Total \\
(thn) & \% within Lama & $.0 \%$ & 100.0 & $.0 \%$ & 100.0 \\
& Mengajar (thn) & & $\%$ & & $\%$ \\
\hline
\end{tabular}


JIPSINDO No. 2, Volume 3, September 2016

\begin{tabular}{|c|c|c|c|c|c|c|}
\hline & & $\begin{array}{l}\text { \% within Kesiapan } \\
\text { guru IPS... }\end{array}$ & $.0 \%$ & $13.6 \%$ & $.0 \%$ & $10.0 \%$ \\
\hline & & $\%$ of Total & $.0 \%$ & $10.0 \%$ & $.0 \%$ & $10.0 \%$ \\
\hline & $10-20$ & Count & 2 & 7 & 5 & 14 \\
\hline & & $\begin{array}{l}\% \text { within Lama } \\
\text { Mengajar (thn) }\end{array}$ & $14.3 \%$ & $50.0 \%$ & $35.7 \%$ & $\begin{array}{r}100.0 \\
\%\end{array}$ \\
\hline & & $\begin{array}{l}\% \text { within Kesiapan } \\
\text { guru IPS... }\end{array}$ & $28.6 \%$ & $15.9 \%$ & $55.6 \%$ & $23.3 \%$ \\
\hline & & $\%$ of Total & $3.3 \%$ & $11.7 \%$ & $8.3 \%$ & $23.3 \%$ \\
\hline & $21-30$ & Count & 5 & 16 & 1 & 22 \\
\hline & & $\begin{array}{l}\% \text { within Lama } \\
\text { Mengajar (thn) }\end{array}$ & $22.7 \%$ & $72.7 \%$ & $4.5 \%$ & $\begin{array}{r}100.0 \\
\%\end{array}$ \\
\hline & & $\begin{array}{l}\% \text { within Kesiapan } \\
\text { guru IPS... }\end{array}$ & $71.4 \%$ & $36.4 \%$ & $11.1 \%$ & $36.7 \%$ \\
\hline & & $\%$ of Total & $8.3 \%$ & $26.7 \%$ & $1.7 \%$ & $36.7 \%$ \\
\hline & $>30$ th & Count & 0 & 15 & 3 & 18 \\
\hline & & $\begin{array}{l}\% \text { within Lama } \\
\text { Mengajar (thn) }\end{array}$ & $.0 \%$ & $83.3 \%$ & $16.7 \%$ & $\begin{array}{r}100.0 \\
\%\end{array}$ \\
\hline & & $\begin{array}{l}\text { \% within Kesiapan } \\
\text { guru IPS... }\end{array}$ & $.0 \%$ & $34.1 \%$ & $33.3 \%$ & $30.0 \%$ \\
\hline & & $\%$ of Total & $.0 \%$ & $25.0 \%$ & $5.0 \%$ & $30.0 \%$ \\
\hline Total & & Count & 7 & 44 & 9 & 60 \\
\hline & & $\begin{array}{l}\% \text { within Lama } \\
\text { Mengajar (thn) }\end{array}$ & $11.7 \%$ & $73.3 \%$ & $15.0 \%$ & $\begin{array}{r}100.0 \\
\%\end{array}$ \\
\hline & & $\begin{array}{l}\text { \% within Kesiapan } \\
\text { guru IPS... }\end{array}$ & $100.0 \%$ & $\begin{array}{r}100.0 \\
\%\end{array}$ & $\begin{array}{r}100.0 \\
\%\end{array}$ & $\begin{array}{r}100.0 \\
\%\end{array}$ \\
\hline & & $\%$ of Total & $11.7 \%$ & $73.3 \%$ & $15.0 \%$ & $\begin{array}{r}100.0 \\
\%\end{array}$ \\
\hline
\end{tabular}

(Sumber: data primer yang diolah, 2014)

Untuk mengetahui ada tidaknya perbedaan kesiapan dalam pembelajaran IPS berbasis kurikulum 2013 antara guru yang memiliki perbedaan lama mengajar dilakukan uji beda dengan $C h i$ Square yang hasilnya dapat dilihat dalam tabel 6. 
Tabel 6

Chi-Square Tests

\begin{tabular}{lrrr}
\hline \hline & Value & df & \multicolumn{2}{c}{$\begin{array}{c}\text { Asymp. Sig. } \\
\text { (2-sided) }\end{array}$} \\
\hline Pearson Chi-Square & $13.598^{\mathrm{a}}$ & 6 & .034 \\
Likelihood Ratio & 16.327 & 6 & .012 \\
Linear-by-Linear & .005 & 1 & .945 \\
Association & 60 & & \\
N of Valid Cases & 60
\end{tabular}

a. 9 cells $(75.0 \%)$ have expected count less than 5 . The minimum expected count is .70 .

Dari hasil analisis Chi Square di atas, perhitungan uji beda signifikansi diperoleh nilai signifikansi sebesar 0,034. Hasil tersebut menunjukkan bahwa nilai signifikansi yang diperoleh lebih kecil dari nilai signifikansi yang telah ditetapkan sebesar 0,05 maka Ho ditolak dan Ha diterima sehingga dapat disimpulkan ada perbedaan kesiapan guru yang memiliki lama mengajar kurang dari 10 tahun, 10 sampai dengan 20 tahun, 21 sampai dengan 30 tahun dan lebih dari 30 tahun dalam implementasi pembelajaran IPS berbasis kurikulum 2013. Perbedaan yang terlihat pada tabel 5 cukup signifikan sehingga dapat dikatakan bahwa terdapat perbedaan kesiapan guru dalam implementasi pembelajaran IPS berbasis kurikulum 2013 ditinjau berdasar lama mengajar. Guru yang memiliki pengalaman mengajar lebih banyak yang ditunjukkan dengan lama mengajar sudah sewajarnya lebih siap untuk menghadapi perubahan kurikulum, karena perubahan kurikulum tidak hanya terjadi saat ini saja. Guru yang memiliki pengalaman mengajar lebih lama tentunya lebih matang, lebih mudah menyesuaikan dengan perubahan sehingga memiliki kesiapan yang lebih tinggi daripada guru yang pengalaman mengajarnya lebih pendek. 
4. Kesiapan guru IPS SMP Kabupaten Sleman dalam implementasi pembelajaran IPS berbasis kurikulum 2013 ditinjau berdasar keikutsertaan diklat kurikulum 2013

Data tentang kesiapan guru IPS SMP Kabupaten Sleman terhadap IPS dalam implementasi pembelajaran IPS berbasis kurikulum 2013 ditinjau berdasar keikutsertaan diklat kurikulum 2013 dilakukan dengan analisis crosstabs atau tabulasi silang pada tabel di bawah ini.

Tabel 7 Kesiapan guru dalam implementasi pembelajaran IPS berbasis kurikulum 2013 berdasar keikutertaan diklat kurikulum 2013

Keikutsertaan Diklat * Kesiapan guru IPS... Crosstabulation

\begin{tabular}{|c|c|c|c|c|c|}
\hline & \multicolumn{3}{|c|}{ Kesiapan guru IPS... } & \multirow[b]{2}{*}{ Total } \\
\hline & & $\begin{array}{l}\text { Cukup } \\
\text { Rendah }\end{array}$ & $\begin{array}{l}\text { Cukup } \\
\text { Tinggi }\end{array}$ & Tinggi & \\
\hline \multirow{9}{*}{$\begin{array}{l}\text { Keikutsertaan } \\
\text { Diklat }\end{array}$} & 1 kali Count & 7 & 42 & 6 & 55 \\
\hline & $\begin{array}{l}\text { \% within } \\
\text { Keikutsertaan } \\
\text { Diklat }\end{array}$ & $12.7 \%$ & $76.4 \%$ & $10.9 \%$ & $\begin{array}{r}100.0 \\
\%\end{array}$ \\
\hline & $\begin{array}{l}\% \text { within } \\
\text { Kesiapan guru } \\
\text { IPS... }\end{array}$ & $100.0 \%$ & $95.5 \%$ & $66.7 \%$ & $\begin{array}{r}91.7 \\
\%\end{array}$ \\
\hline & $\%$ of Total & $11.7 \%$ & $70.0 \%$ & $10.0 \%$ & $\begin{array}{r}91.7 \\
\%\end{array}$ \\
\hline & 2 kali Count & 0 & 1 & 2 & 3 \\
\hline & $\begin{array}{l}\text { \% within } \\
\text { Keikutsertaan } \\
\text { Diklat }\end{array}$ & $.0 \%$ & $33.3 \%$ & $66.7 \%$ & $\begin{array}{r}100.0 \\
\%\end{array}$ \\
\hline & $\begin{array}{l}\text { \% within } \\
\text { Kesiapan guru } \\
\text { IPS... }\end{array}$ & $.0 \%$ & $2.3 \%$ & $22.2 \%$ & $5.0 \%$ \\
\hline & $\%$ of Total & $.0 \%$ & $1.7 \%$ & $3.3 \%$ & $5.0 \%$ \\
\hline & 3 kali Count & 0 & 1 & 0 & 1 \\
\hline
\end{tabular}




\begin{tabular}{|c|c|c|c|c|c|c|}
\hline & & $\begin{array}{l}\% \text { within } \\
\text { Keikutsertaan } \\
\text { Diklat }\end{array}$ & $.0 \%$ & $\begin{array}{r}100.0 \\
\%\end{array}$ & $.0 \%$ & $\begin{array}{r}100.0 \\
\%\end{array}$ \\
\hline & & $\begin{array}{l}\% \text { within } \\
\text { Kesiapan guru } \\
\text { IPS... }\end{array}$ & $.0 \%$ & $2.3 \%$ & $.0 \%$ & $1.7 \%$ \\
\hline & & $\%$ of Total & $.0 \%$ & $1.7 \%$ & $.0 \%$ & $1.7 \%$ \\
\hline & $>3$ & Count & 0 & 0 & 1 & 1 \\
\hline & & $\begin{array}{l}\text { \% within } \\
\text { Keikutsertaan } \\
\text { Diklat }\end{array}$ & $.0 \%$ & $.0 \%$ & $\begin{array}{r}100.0 \\
\%\end{array}$ & $\begin{array}{r}100.0 \\
\%\end{array}$ \\
\hline & & $\begin{array}{l}\% \text { within } \\
\text { Kesiapan guru } \\
\text { IPS... }\end{array}$ & $.0 \%$ & $.0 \%$ & $11.1 \%$ & $1.7 \%$ \\
\hline & & $\%$ of Total & $.0 \%$ & $.0 \%$ & $1.7 \%$ & $1.7 \%$ \\
\hline \multirow[t]{4}{*}{ Total } & & Count & 7 & 44 & 9 & 60 \\
\hline & & $\begin{array}{l}\text { \% within } \\
\text { Keikutsertaan } \\
\text { Diklat }\end{array}$ & $11.7 \%$ & $73.3 \%$ & $15.0 \%$ & $\begin{array}{r}100.0 \\
\%\end{array}$ \\
\hline & & $\begin{array}{l}\% \text { within } \\
\text { Kesiapan guru } \\
\text { IPS... }\end{array}$ & $100.0 \%$ & $\begin{array}{r}100.0 \\
\%\end{array}$ & $\begin{array}{r}100.0 \\
\%\end{array}$ & $\begin{array}{r}100.0 \\
\%\end{array}$ \\
\hline & & $\%$ of Total & $11.7 \%$ & $73.3 \%$ & $15.0 \%$ & $\begin{array}{r}100.0 \\
\%\end{array}$ \\
\hline
\end{tabular}

(Sumber: data primer yang diolah, 2014)

Untuk mengetahui ada tidaknya perbedaan kesiapan dalam pembelajaran IPS berbasis kurikulum 2013 antara guru yang memiliki frekuensi keikutsertaan diklat sebanyak 1 kali, 2 kali, 3 kali, dan lebih dari 3 kali berdasar analisis statistik, dilakukan uji beda dengan Chi Square yang hasilnya dapat dilihat dalam tabel 8 .

Tabel 8. Chi-Square Tests

\begin{tabular}{lrrr}
\hline \hline & Value & Df & $\begin{array}{c}\text { Asymp. Sig. } \\
(2-\text { sided })\end{array}$ \\
\hline Pearson Chi-Square & $13.109^{a}$ & 6 & .041 \\
Likelihood Ratio & 9.602 & 6 & .142 \\
Linear-by-Linear & 5.557 & 1 & .018 \\
Association & & &
\end{tabular}


$\mathrm{N}$ of Valid Cases $\quad 60$

a. 9 cells $(75.0 \%)$ have expected count less than 5 .

The minimum expected count is . 12 .

Dari hasil analisis Chi Square di atas, perhitungan uji beda signifikansi diperoleh nilai signifikansi sebesar 0,041. Hasil tersebut menunjukkan bahwa nilai signifikansi yang diperoleh lebih kecil dari nilai signifikansi yang telah ditetapkan sebesar 0,05 maka Ho ditolak dan Ha diterima sehingga dapat disimpulkan ada perbedaan kesiapan guru yang memiliki frekuensi keikutsertaan diklat kurikulum 2013 sebanyak 1 kali, 2 kali, 3 kali, dan lebih dari 3 kali dalam implementasi pembelajaran IPS berbasis kurikulum 2013. Perbedaan yang terlihat pada tabel 8 cukup signifikan sehingga dapat dikatakan bahwa terdapat perbedaan kesiapan guru dalam implementasi pembelajaran IPS berbasis kurikulum 2013 ditinjau berdasar keikutsertaan diklat kurikulum 2013. Hal tersebut dimungkinkan karena dalam setiap kali diklat guru memperoleh pengetahuan yang baru yang dapat meningkatkan kesiapan guru dalam implementasi pembelajaran. Seharusnya guru yang lebih sering mengikuti diklat memiliki kesiapan yang lebih tinggi.

\section{Simpulan}

Berdasarkan hasil penelitian dan pembahasan yang telah diuraikan dapat ditarik kesimpulan sebagai berikut:

a. Tidak terdapat perbedaan kesiapan guru IPS SMP Kabupaten Sleman dalam implementasi pembelajaran IPS berbasis kurikulum 2013 antara guru laki-laki dan guru perempuan.

b. Tidak terdapat perbedaan kesiapan guru IPS SMP Kabupaten Sleman dalam implementasi pembelajaran IPS berbasis kurikulum 2013 antara guru yang memiliki tingkat pendidikan terakhir PGSLP, D3, S1 dan S2. 
JIPSINDO No. 2, Volume 3, September 2016

c. Terdapat perbedaan kesiapan guru IPS SMP Kabupaten Sleman dalam implementasi pembelajaran IPS berbasis kurikulum 2013 antara guru yang memiliki lama mengajar kurang dari 10 tahun, 10 sampai dengan 20 tahun, 20 sampai dengan 30 tahun dan lebih dari 30 tahun.

d. Terdapat perbedaan kesiapan guru IPS SMP Kabupaten Sleman dalam implementasi pembelajaran IPS berbasis kurikulum 2013 antara guru yang memiliki keikutsertaan diklat dalam frekuensi 1 kali, 2 kali, 3 kali dan lebih dari 3 kali.

\section{Saran}

Dalam rangka memberikan alternatif pemecahan terhadap perbedaan kesiapan guru dalam implementasi pembelajaran IPS berbasis kurikulum 2013 terdapat beberapa hal yang perlu dilakukan antara lain:

a. Guru IPS SMP harus memiliki keyakinan dan berpikiran positif terhadap implementasi kurikulum 2013 kaitannya dengan pembelajaran IPS.

b. Guru hendaknya mampu meningkatkan pengetahuan dan keterampilan dalam implementasi pembelajaran IPS baik meliputi perencanaan, pelaksanaan, dan penilaian pembelajaran IPS sesuai tuntutan kurikulum 2013 dengan cara meningkatkan keikutsertaannya dalam diklat dan mengikuti forum MGMP IPS.

c. Guru hendaknya menambah keikutsertaannya pada diklat kurikulum 2013 untuk menambah informasi mengenai kurikulum 2013 dan meningkatkan kesiapan guru dalam implementasi kurikulum 2013. 
JIPSINDO No. 2, Volume 3, September 2016

d. Guru hendaknya meningkatkan pengalaman mengajar agar lebih siap dalam implementasi pembelajaran IPS berbasis kurikulum 2013.

\section{Daftar Pustaka}

Dalyono. (2005). Psikologi Pendidikan. Jakarta: Rineka Cipta.

Depdiknas. 2005. Undang-Undang RI Nomor 20 Tahun 2003 tentang Sistem Pendidikan Nasional.

Hermanto Sofyan. 1991. Kesiapan Kerja Siswa STM Sejawa. Laporan Penelitian. FPTK IKIP Yogyakarta

Imas Kurniasih \& Berlin Sani. 2014. Implementasi Kurikulum 2013 Konsep dan Penerapan. Surabaya: kata Pena

Kartini Kartono .1997. Kamus lengkap Psikologi. Diterjemahkan dari Chaplin J.P. Jakarta : Grafindo Persada

Kemdikbud. 2013. Permendikbud No. 68 Tahun 2013 Tentang Standar Kerangka Dasar dan Struktur Keilmuan Sekolah Menengah Pertama/Madrasah Tsanawiyah. Jakarta: Kemdikbud

Rika Isharyanti. 2011. Pengaruh Praktik Industri, Informasi Dunia Kerja dan Motivasi Kerja terhadap Kesiapan Kerja Siswa Kelas XII Program Keahlian Administrasi Perkantoran SMK N 1 Tempel. Skripsi. Pendidikan Administrasi Perkantoran FISE UNY.

Slameto. 2010. Belajar dan Faktor-Faktor yang Mempengaruhinya.Jakarta: Rineka Cipta.

Suharsimi Arikunto. 2006. Prosedur Penelitian Suatu Pendekatan Praktek. Jakarta: Rineka Cipta 